\title{
Urban non-engineered buildings in Mérida, Venezuela. Seismic performance and proposals for retrofit and for new construction
}

\author{
Viviendas de auto-construcción en Mérida, Venezuela. Comportamiento \\ sísmico y propuestas de rehabilitación y de nueva construcción \\ F. López-Almansa $^{(*)}$, L.G. Pujades ${ }^{(*)}$, A. Castillo ${ }^{(* *)}$
}

\begin{abstract}
The seismic risk for an informal settlement in Mérida ("La Milagrosa”) is qualitatively assessed and retrofit strategies are proposed. The buildings in the settlement are thoroughly examined and four prototype buildings are chosen to represent the vast majority of houses in "La Milagrosa". The structural behavior of these buildings under gravity loads and seismic actions is deeply analyzed; this study shows that the prototype buildings are unsafe for gravity loads, and that the seismic demands largely exceed their capacity. Based on these conclusions, feasible retrofit strategies are proposed, together with draft recommendations for new similar constructions. Earlier quantitative estimative appraisals show that the proposed seismic strengthening measures can be very effective in reducing fatalities and economical losses, and are significantly more cost-efficient than reconstruction-based approaches. These conclusions might be generalized to many non-engineered urban areas in earthquake-prone regions of the developing world.
\end{abstract}

Keywords: Vulnerability; risk; mitigation; non-engineered buildings; seismic strengthening; Venezuela.

\section{RESUMEN}

Se evalúa cualitativamente el riesgo sísmico para un asentamiento informal en Mérida («La Milagrosa») y se proponen estrategias de rehabilitación sísmica. Se eligen cuatro edificios prototipo que representan a la gran mayoría de los de «La Milagrosa». El comportamiento estructural de estos edificios se analiza en profundidad y se concluye que los edificios no son seguros para cargas gravitatorias, y que las solicitaciones sísmicas son muy superiores a su capacidad. A partir de estas conclusiones, se proponen estrategias de rehabilitación sísmica, junto con recomendaciones de proyecto para nuevas construcciones de características similares. Evaluaciones cuantitativas estimativas previas muestran que las medidas propuestas de fortalecimiento sísmico pueden ser muy eficaces en la reducción de muertes y de pérdidas económicas; siendo significativamente más rentables que los planteamientos basados en la reconstrucción. Estas conclusiones pueden generalizarse a otros muchos asentamientos informales en zonas urbanas situadas en regiones de sismicidad alta en países en desarrollo.

Palabras clave: Vulnerabilidad; riesgo; mitigación; viviendas de auto-construcción; rehabilitación sísmica; Venezuela.

${ }^{(*)}$ Universidad Politécnica de Cataluña. Barcelona (España).
${ }^{(*)}$ Universidad de los Andes. Mérida (Venezuela).
Persona de contacto/Corresponding author: francesc.lopez-almansa@upc.edu (F. López-Almansa)

Cómo citar este artículo/Citation: López-Almansa, F., Pujades, L. G., Castillo, A. (2015). Urban non-engineered buildings in Mérida, Venezuela. Seismic performance and proposals for retrofit and for new construction. Informes de la Construcción, 67(537): e050, doi: http://dx.doi.org/10.3989/ic.12.091.

Licencia / License: Salvo indicación contraria, todos los contenidos de la edición electrónica de Informes de la Construcción se distribuyen bajo una licencia de uso y distribución Creative Commons Reconocimiento no Comercial 3.o. España (cc-by-nc). 


\section{INTRODUCTION}

During the 2oth century, migration from rural to urban areas led to the development of large cities with poor areas characterized by low quality constructions. Consequently, densely populated informal settlements are now increasingly common in most large cities in Southern and Central America and other developing regions, including China, India and other Asian and African countries. Housing in these areas is generally non-engineered and self-constructed. Since the buildings are of poor quality and were not designed in accordance with the seismic code provisions, they are expected to be highly vulnerable to seismic motions. In addition, settlements of this type frequently occupy high seismic hazard areas and are therefore vulnerable to earthquake-induced effects such as landslides and liquefaction. This combination of hazard and vulnerability generates a significant seismic risk (1).

Excluding extremely precarious housing, according to the "Encyclopedia of housing construction types in seismically prone areas of the world" (2) non-engineered dwellings can be broadly classified into the following seven groups in relation to the lateral load resisting system (2) (3) (4): (i) adobe or earth houses, with timber or similar roofs and slabs; (ii) stone masonry, which includes buildings with rubble, field and simple stone walls with wooden floors; (iii) timber houses, which can incorporate either frames or posts and ties; (iv) unconfined unreinforced masonry walls; (v) confined unreinforced masonry walls, in which the confinement effect is provided by RC posts cast after the walls have been erected; (vi) RC frames, which are usually supplemented with infill walls, although in any case the main frames are able to resist the vertical loads; and (vii) intermediate RC frames and confined masonry walls, which consist of a light RC frame which is then filled with unreinforced masonry walls. Importantly, the latter group cannot be considered simply as RC frames, since the strength of the frame is not sufficient to withstand the gravity loads; as well, it cannot be considered as confined masonry walls, because the columns, which are cast before the walls are constructed, do not provide enough confinement and the bottom walls have no foundation.

Of these construction techniques, adobe, stone masonry and timber (groups 1 to 3 ) are more commonly used in rural areas because these materials are more readily available. In contrast, masonry and concrete-based construction (groups 4 to 7) are widely and increasingly used in informal urban areas. Nevertheless, all of these buildings are vulnerable to earthquakes because they are characterized by high lateral stiffness and low ductility.

The main goals of this research are to analyze the seismic risk of informal urban settlements and to propose simple and feasible -but effective- seismic retrofit measures to protect buildings in these areas against earthquakes. The city of Mérida in Venezuela was chosen as a test site. "La Milagrosa" area is a typical informal settlement of the city with a wide variety of ground and building conditions. The terrain in "La Milagrosa" combines steep and flat areas and soft and hard soils. Buildings are mainly intermediate RC frames and confined masonry walls (group 7). The area is suitable for the aims of this study because it is representative of the suburbs of many large conurbations in developing countries in seismic-prone regions. The study of "La Milagrosa" consists of the following steps: (i) vulnerability and risk analysis; (ii) classification and structural analysis of building stock; (iii) proposal of seismic strengthening measures, and (iv) socio-economic cost-benefit appraisal. This paper focuses in steps 2 and 3. As well draft recommendations for new similar constructions are specified. The works (5) (6) include quantitative estimates of the benefits of the proposed retrofit strategies. As well, references 5 and 6 include quantitative estimative appraisals based on the concept of "seismic vulnerability index" and on semi-empirical damage functions; such studies show that the proposed strengthening actions are effective in reducing fatalities and economical losses, and are clearly more costefficient than reconstruction-based approaches.

\section{MÉRIDA AND "LA MILAGROSA" SETTLEMENT}

Mérida is located in the Andean mountain range in Venezuela and was founded in 1558 on a plateau between the Albarregas and Chama rivers, which divide the city into two areas separated by a shallow and deep canyon. The Chama river canyon confines the urban area on one side of the city, at the base of the Sierra Nevada mountain chain. Altitudes in the tableland range from around $1100 \mathrm{~m}$ in the southeastern part to $1900 \mathrm{~m}$ at the northwestern limits. Mérida has grown steadily since it was founded and now has more than 300,000 inhabitants. In the last four decades a number of informal settlements have grown around the city limits and are now home for approximately one third of the city's population. These settlements are the most densely populated areas of the city and have the highest vulnerability and even the greatest seismic hazard in some steep sites. "La Milagrosa" is a suburb located in the northeastern part of the city. Figure 1 shows the elevation range in Mérida, the main rivers and streets and the location of the settlement.

This suburb was chosen because its buildings are representative of those found in many informal settlements in developing countries. The area is divided into four sectors: "La Milagrosa", "Cristo Rey", "Los Molinos" and "Miranda". Figure 2 shows a map of the suburb and Table 1 lists the main features of each sector.

The relief in this area is extremely varied, with gradients ranging from near flat (o to $5 \%$ ) to steep (60\%). Clawy rock outcrops predominate in the steeper and upper parts, and there are average-to-good-quality soils in the rest of the

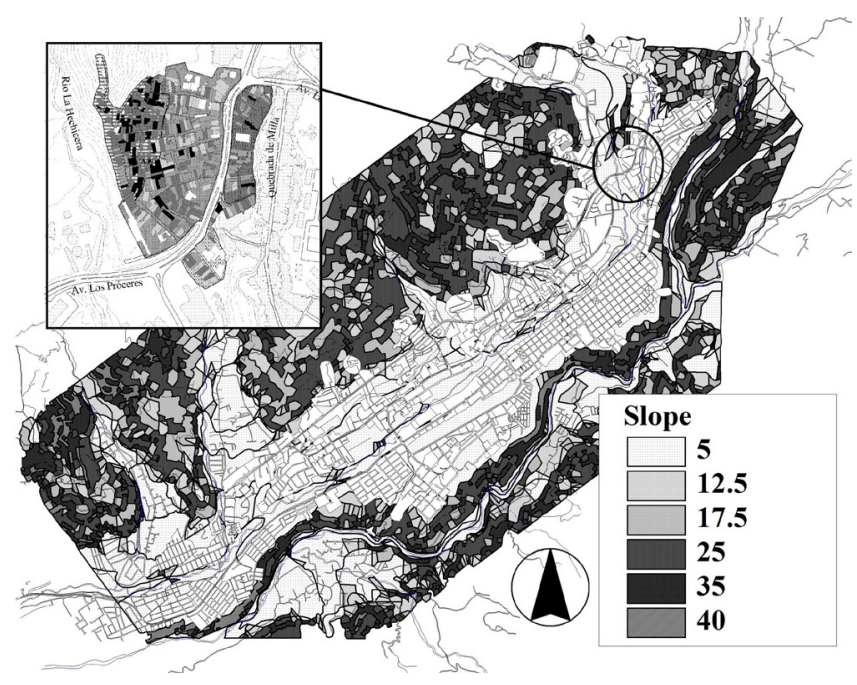

Figure 1. Elevation range, rivers and streets of the Mérida plateau. 


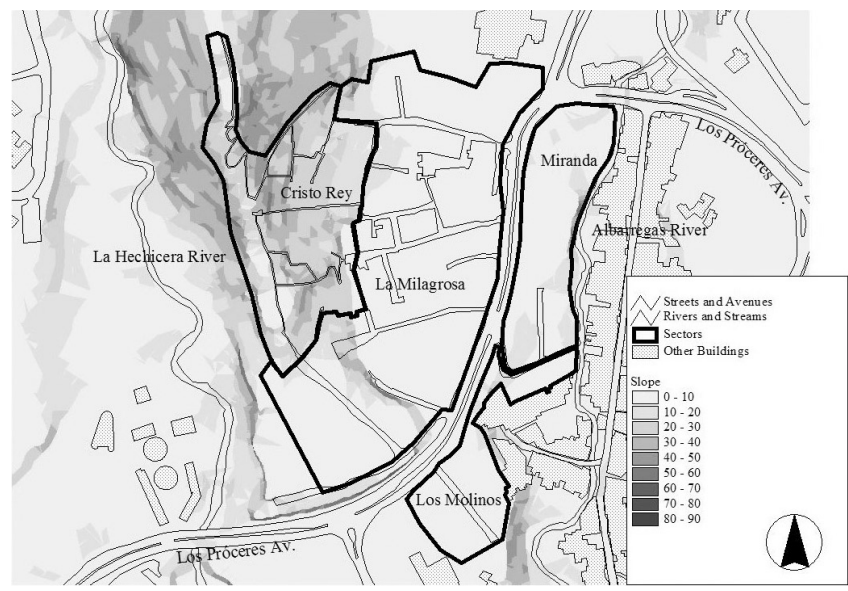

Figure 2. Sectors in "La Milagrosa” settlement.

area. The design stress is estimated as $0.15 \mathrm{MPa}$, since no tests have been carried out locally and there is no information about geotechnical columns. With the exception of landslide risk, the soil strength is not critical; since the buildings are light and have a small number of floors, the vertical stresses they exert are comparatively low. "La Milagrosa" settlement contains mainly houses, which can be classified into groups according to their resisting systems, as shown in Table 2.

The last two categories in Table 2 correspond to engineered constructions. The data show that $95 \%$ of the buildings are non-engineered intermediate $R C$ frames and confined masonry walls (group 7), so the paper focuses mainly on this structural type. Approximately $85 \%$ of the buildings have a rectangular plan configuration, with typical plan dimensions of $5.5 \times 16.5 \mathrm{~m}$. The main occupancy is housing, and in the most common scenario a family of five (parents and three children) occupies each floor. Additional floors are constructed to house new families, resulting in a typical vertical growth pattern, although the buildings rarely exceed three floors. This pattern is common to many informal urban settlements worldwide. Figure 3 shows a map with the plan configuration and the number of floors of the buildings in "La Milagrosa" settlement.

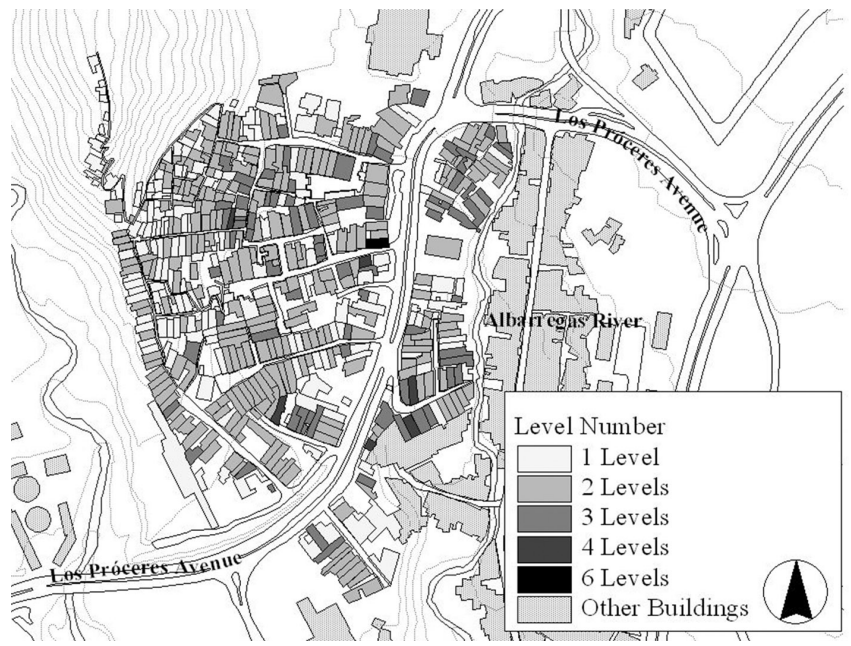

Figure 3. Plan configuration and number of floors of buildings in "La Milagrosa" settlement.

\section{PROTOTYPE BUILDINGS IN "LA MILAGROSA"}

Figure 4 shows a sketch of the most commonly used type of construction. The main structural features of the buildings are described below. More detailed descriptions can be found in (5).

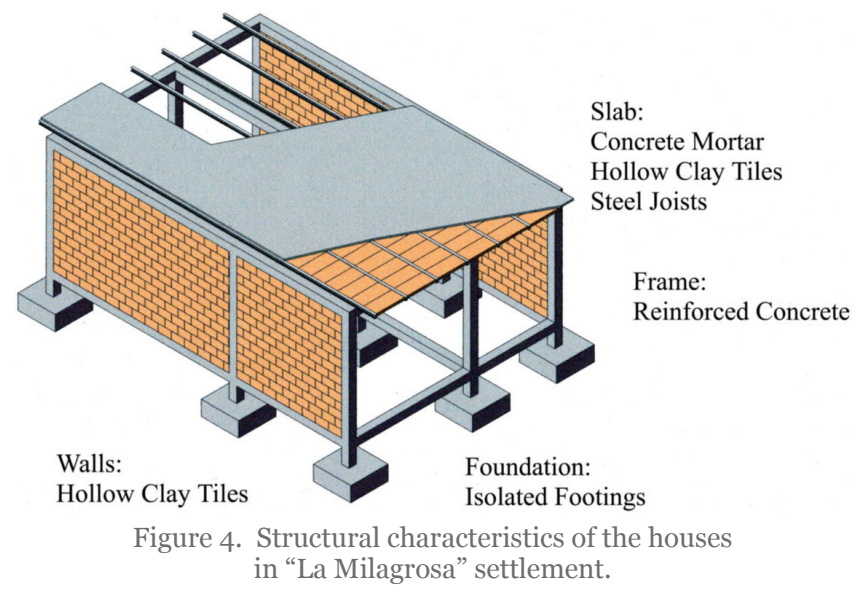

Table 1. Description of sectors in "La Milagrosa" area.

\begin{tabular}{|l|c|c|c|c|}
\hline Sector & Surface (Ha) & N. $^{\mathbf{o}}$ of buildings & N. $^{\mathbf{o}}$ of inhabitants & Year of foundation \\
\hline La Milagrosa & 5.68 & 219 & 1608 & 1960 \\
\hline Cristo Rey & 2.83 & 199 & 1232 & 1962 \\
\hline Los Molinos & 0.82 & 37 & 280 & 1962 \\
\hline Miranda & 1.31 & 78 & 620 & 1965 \\
\hline Total & $\mathbf{1 0 . 6 4}$ & $\mathbf{5 3 3}$ & $\mathbf{3 7 4 0}$ & \\
\hline
\end{tabular}

Table 2. Distribution of building types in "La Milagrosa".

\begin{tabular}{|l|c|c|}
\hline Building type & No of buildings & Percentage of total \\
\hline Intermediate RC frames and confined masonry walls & 506 & 94.93 \\
\hline Unconfined unreinforced masonry walls & 10 & 1.88 \\
\hline RC frames & 2 & 0.38 \\
\hline Steel frames & 9 & 1.69 \\
\hline RC columns and steel truss beams & 6 & 1.13 \\
\hline Total & $\mathbf{5 3 3}$ & $\mathbf{1 0 0}$ \\
\hline
\end{tabular}


Posts and ties constitute a light 3D RC frame, with an average square section in the beams (tie-beams) and columns (tiecolumns) of $20 \times 20 \mathrm{~cm}$. The beam-column connections do not have special detailing or stirrups; however, the longitudinal re-bars of the beams have hooked ends. The compressive strength of the concrete was measured with a Schmidt hammer, and the characteristic value is approximately $10 \mathrm{MPa}$. In some cases the joined members are poorly aligned and connected. The supporting walls are built after the posts in running (stretcher) bond, without reinforcement and using low-quality mortar. The bricks are hollow and not intended for structural use. The characteristic shear and compressive strengths of the brick-mortar assembly are conservatively estimated as $0.08 \mathrm{MPa}$ and $0.35 \mathrm{MPa}$, respectively (7). The friction coefficient is taken as 0.4 (8). The walls are usually erected without foundation. The posts are supported by isolated RC footings. The cladding walls run around the entire perimeter, with openings in the front and rear sides only; on the first floor there is usually one window and one door at the front and two windows at the rear. On the upper levels, there are either two windows or, if there is a balcony, one door and one window at the front and the rear. Not all of the partition walls are aligned with the frame, and in some cases they are not vertically aligned. The walls beneath slabs are referred to as "topped" because the beams produce a certain degree of confinement; those under light roofs are referred to as "untopped" because the roof is weak and untied and, therefore, does not produce any confinement. The roofing is lightweight and consists mainly of zinc sheathing over steel beams. The roofs are not well fixed to the support elements. The slabs are built using I-shaped steel beams, which are arranged parallel to the longitudinal axis of the building and supported by the transverse RC ties. The inter-axial spacing is filled with hollow clay blocks. The slabs are topped with a thin compressive concrete layer reinforced with a light welded mesh. The first level usually has a front cantilever of between 700 and $900 \mathrm{~mm}$, which supports either masonry cladding walls or balconies. The stairs are constructed either inside or outside the building and are made of steel or reinforced concrete. Although the general quality of the constructions is poor, it is better than expected given their low quality. Some common deficiencies include broken masonry units and discontinuities in the walls, bonding mortar that is not even resistant to scratching, unaligned horizontal blocks, roofs that are not properly tied, shrinkage cracks in floors, irregularities, cavi-
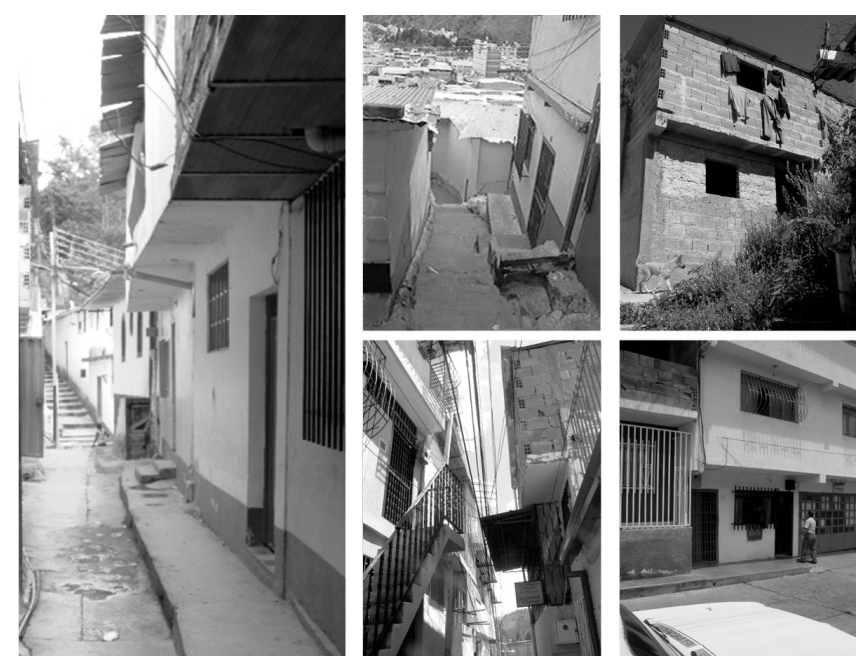

Figure 5. Buildings in "La Milagrosa" settlement. ties and erosion in the posts and ties, and insufficient reinforcement cover. In some steep sites, soil erosion is observed around the foundations. Finally, no relevant pathologies are observed. Minor problems include humidity, water filtration, and cracks in the wall plaster.

Figure 5 shows some representative pictures of the houses in "La Milagrosa" settlement.

Four prototype buildings were selected to represent the vast majority of houses in "La Milagrosa". Figure 6 and Figure 7 display, respectively, 3 -D views and the plan configurations of these prototypes.

The number of levels is a relevant feature used in the classification of buildings in "La Milagrosa". For the NENG-RC typology, the most common are the two-story buildings (52 \%), followed by the single-story ones ( $32 \%)$ and finally, by the three-story buildings (16\%). The number of floors was used

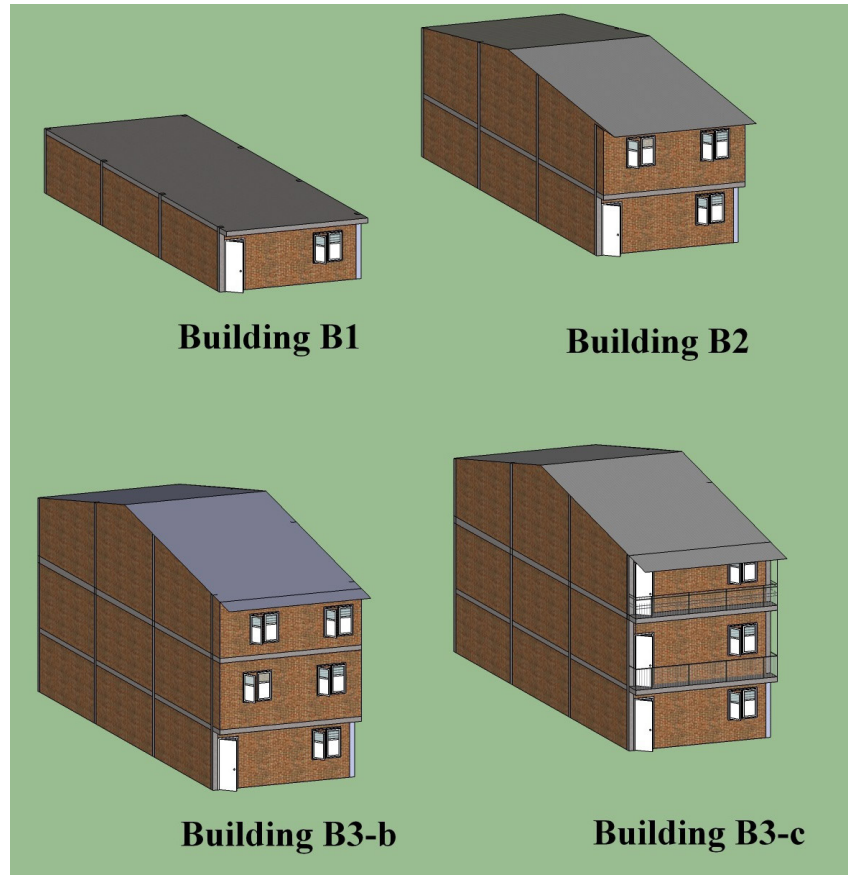

Figure 6. Prototype buildings.
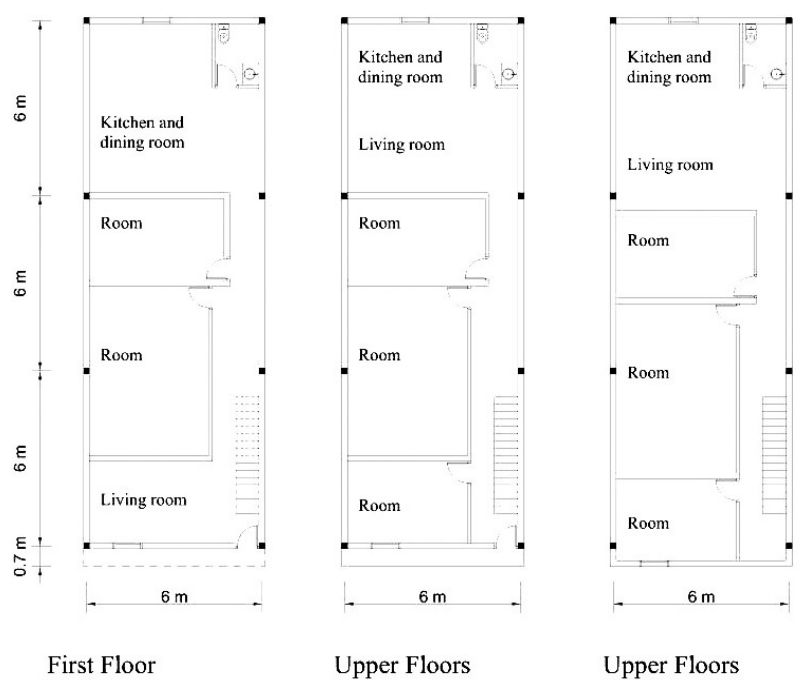

First Floor Upper Floors Upper Floor

Buildings: B1, B2 and B3 Buildings: B2 and B3-b Buildings: B2 and B3-c Figure 7. Plan configurations of the prototype buildings. 
to select initially three building prototypes, one-, two- and three-story buildings, termed B1, B2 and B3, respectively (see Figure 6). All of them are symmetrical, e.g. the centroids and the stiffness centers are roughly coincident. The average story height is about $2.80 \mathrm{~m}$. Buildings $\mathrm{B} 2$ and $\mathrm{B} 3$ are topped with light roofs while building B1 is topped with a conventional slab (since it represents a group of constructions intended to grow vertically), as discussed previously. A further distinction is incorporated in building $\mathrm{B}_{3}$, originating $\mathrm{B}_{3}-\mathrm{b}$ (with balconies) and $\mathrm{B}_{3}-\mathrm{c}$ (with cantilevered walls). When $\mathrm{B}_{3}$ term is used, it will refer to both $\mathrm{B}_{3}-\mathrm{b}$ and $\mathrm{B}_{3}-\mathrm{c}$. Finally, the main features of the four prototype buildings are:

- B1. It is a building with one story and topped with a slab.

- B2. It is a building with two stories and topped with a light roof. The second floor might have either a cantilever or a balcony; this distinction is considered irrelevant from the seismic behavior point of view since (i) the upper walls lack both of collar beam and of proper ties and, hence, their inplane strength will never be developed and (ii) the roof is very light and, consequently, the demanding lateral forces on the upper walls are rather small.

- B3-b. It is a building with three stories and topped with a light roof. The second and third floors have a balcony; this is considered relevant from the seismic behavior point of view since the second floor front wall is coplanar with the frame, being fully able to cooperate in the seismic strength.

- B3-c. It is a building with three stories and topped with a light roof. The second and third floors have a cantilever; this is considered relevant from the seismic behavior point of view since the second floor front wall is not coplanar with the frame, being only partially able to cooperate in the seismic strength.

The representative buildings with average features are assumed to be built in the same fashion as in the previous descriptions, i.e. regular in plan with the characteristic common conditions, structural layout and dimensions and detailing of structural members, roofing, and infill walls (cladding and partitioning). Noticeably, in spite that building B3-c is asymmetric, there is only eccentricity among the center of stiffness and of gravity in the second and third floors; therefore, this has only a reduced influence on the torsional seismic behavior.

\section{BEHAVIOR OF THE PROTOTYPE BUILDINGS UNDER GRAVITY LOADS}

In this section we analyze the strength of the prototype buildings for vertical loads. A more detailed description can be found in (5). The following paragraphs describe the overall performance of frames, walls and slabs, respectively.

- Posts and ties. The structural analysis of the transversal frames (those supporting the joists, as shown in Figure 4) shows that they do not have the capacity to support the weight of the building, even under serviceability conditions. Consequently, the vertical loads are largely supported by the walls. These buildings must therefore be considered as intermediate RC frames - confined masonry walls according to the classification of non-engineered dwellings given in the Introduction.
- Walls. Even if we disregard the contribution of the posts, the assumed compressive strength of the masonry is sufficient to withstand the gravity forces. Even for buildings $\mathrm{B}_{3}$, the average compressive stress does not exceed the strength of the masonry. However, it would be dangerous to add another floor.

- Slabs. The structural analysis of the steel joists (see Figure 4) shows that, if we disregard the contribution of the top layer, the maximum normal stress largely exceeds the steel yield point. Consequently, the contribution of the concrete layer must be considered. In any case, the slabs are unsafe according to regulatory standards.

From these verifications we can see that the demands exceed the strength. However, no structural pathologies have been observed or reported. This apparent inconsistency can be explained by the difference between serviceability conditions and ultimate limit states, by the discrepancy between the actual live loads and those considered in the analysis, and by the conservative simplifications assumed.

\section{SEISMIC ANALYSIS OF THE PROTOTYPE BUILDINGS}

In this section we analyze the seismic performance of the prototype buildings. A more detailed description can be found in (5).

The horizontal seismic behavior of the prototype buildings is represented using lumped-mass models. Since the walls are significantly stiffer than the posts, they bear most of the horizontal forces; therefore, the position of the center of rigidity is governed by the distribution of the walls, taking into account the openings. Figure 7 shows that the buildings have a high degree of plan symmetry, because their eccentricities in both directions between the centers of mass and rigidity do not exceed $5 \%$ of the total building sizes. Consequently, the behavior in each horizontal direction is represented by using a model with one degree of freedom per floor.

The equivalent force demands are determined according to the Venezuelan seismic design code (9) by following the "Equivalent Static Method".

The values of the parameters characterizing the response spectrum are given next.

- The maximum horizontal acceleration coefficient is $A_{\mathrm{o}}=0.3 \mathrm{~g}$ (seismic zone 5 , termed "high seismic risk").

- The correction factor (accounting for the soil type) ranges in between $\varphi=0.7$ (corresponding to spectral shape S2) for extremely soft soils, and $\varphi=1$ for rock or very stiff soils (corresponding to spectral shape S1). In "La Milagrosa" settlement the soil type can be classified as "stiff or dense" soil. Hence, $\varphi=0.9$ and the spectral shape is $\mathrm{S} 2$.

- The importance factor is $\alpha=1$ as the housings belong to building group B2 (housing units).

- The period $T^{*}$ initiating the descendant branch of the spectrum is $T^{*}=0.7 \mathrm{~s}$.

- The average amplification factor is $\beta=2.6$ and the exponent of the descendant branch is $p=1$. 
- The response reduction factor depends on the type of structure and on the design level which ranges in between level 1 (design for gravity loads only) and 3 (code-compliant earthquake-resistant design). In "La Milagrosa” settlement, the poor detailing of concrete members (which are characteristic of non-ductile RC structures) leads to assume the reduction factor as $R=1$ (no ductility). This non-ductile feature of the buildings, locates them in the non-compliant side of the code; however, the conservative decision taken is to use no reduction factor for the estimation of the design spectra. When a given building does not have ductility, the earthquake demand is expected to be taken in the elastic domain; although this is very difficult to achieve in practice, it serves in this case, as assessment procedure.

The fundamental periods $T$ of the buildings in both horizontal directions are obtained from the semi-empirical expressions given in this code: for prototype B1, $T=0.11 \mathrm{~s}$; for prototype B2, $T=0.19 \mathrm{~s}$; and for prototypes B3, $T=0.26 \mathrm{~s}$. Except for building B1, the periods lie inside the plateau of the design spectrum (in between $T^{*} / 4$ and $T^{*}$ ); therefore, the accurate determination of the fundamental periods might be, in the considered cases, of little practical interest. The torsion effects generated by accidental eccentricities between the centers of mass and of rigidity are conservatively represented by multiplying the demanding equivalent lateral forces by 1.15 . This value has been selected as an average between the forces corresponding to the outer frames or walls (increased by a factor of 1.3) and those for the center positions. The simultaneity among the seismic inputs in both directions has been represented by the combination of the seismic forces in one direction with the $30 \%$ of the forces in the orthogonal one (9); however, this is rather irrelevant as the elements intended to resists the forces in both directions are not the same. The weight of buildings B1, and B2 and $\mathrm{B} 3$ are 383,724 and $1265 \mathrm{kN}$, respectively. The demanding forces are shown in Table 3.

Table 3. Lateral force demands.

\begin{tabular}{|l|c|c|c|}
\hline Prototype building & $\boldsymbol{F}_{\mathbf{1}}(\mathbf{k N})$ & $\boldsymbol{F}_{\mathbf{2}}(\mathbf{k N})$ & $\boldsymbol{F}_{\mathbf{3}}(\mathbf{k N})$ \\
\hline B1 & 309 & - & - \\
\hline B2 & 335 & 227 & - \\
\hline B3-b and B3-c & 237 & 475 & 241 \\
\hline
\end{tabular}

The walls are much stiffer horizontally than the RC frames; consequently, most of the lateral forces are carried by the walls before any damage is suffered. Several failure modes are possible if the building is subjected to greater forces (10):

- Shear failure of topped walls accompanied by failure of posts. This mode corresponds to failure of the masonry along horizontal mortar courses, generally at the mid-height of the panel. The resistance of the walls is determined by classical Mohr-Coulomb models; only the friction term can be accounted for because the contribution of the cohesion is not reliable for cyclic behavior. The effect of openings is compensated for by subtracting from the wall length the segments intercepted by the openings, see Figure 8. The resistance of the posts to shear failure is obtained according to the ACI criterion for seismic behavior (11); the contribution of the transversal steel is disregarded, since the excessive separation between consecutive stirrups allows shear cracks to form. Classical push-over analysis is used to determine the resistance of the posts to failure by plastic hinge formation; since sufficient rotation capacity is not provided (mainly due to the lack of transversal confinement), it is conservatively assumed that the posts fail after the first set of plastic hinges has formed.

- Diagonal strut compression failure of the topped walls accompanied by failure of confining elements. These walls must be in-plane with the posts and ties; otherwise there are no adjacent vertical supporting elements to provide diagonal compression. The strength of the walls is determined by classical strut-and-tie models (10) by considering the influence of the openings. Figure 9 shows failure mechanisms for different openings' configurations.

- Collapse of unsupported elements. Due to the vertical component of the seismic action, some unsupported elements (i.e. vertically discontinuous walls and, in building B3-c, cantilevered walls) are at risk from vertical accelerations that could cause them to collapse. This is a serious risk, because the walls carry most of the weight and the supporting ties and slabs are already overloaded by the gravity demand.

- Out-of-plane failure of the untopped walls. The resistance to this failure mode is difficult to estimate. Furthermore, it is unreliable given the poor quality of the mortar and the absence of upper collar beams and reliable ties (the roofs are light and weak).

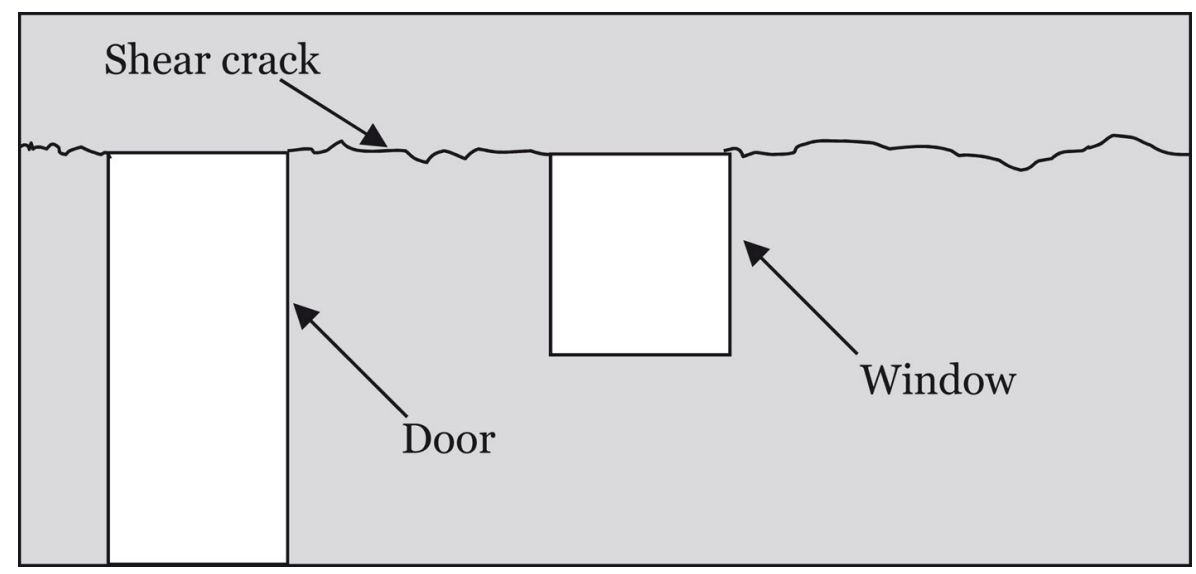

Figure 8. Shear failure mode for a wall with openings. 


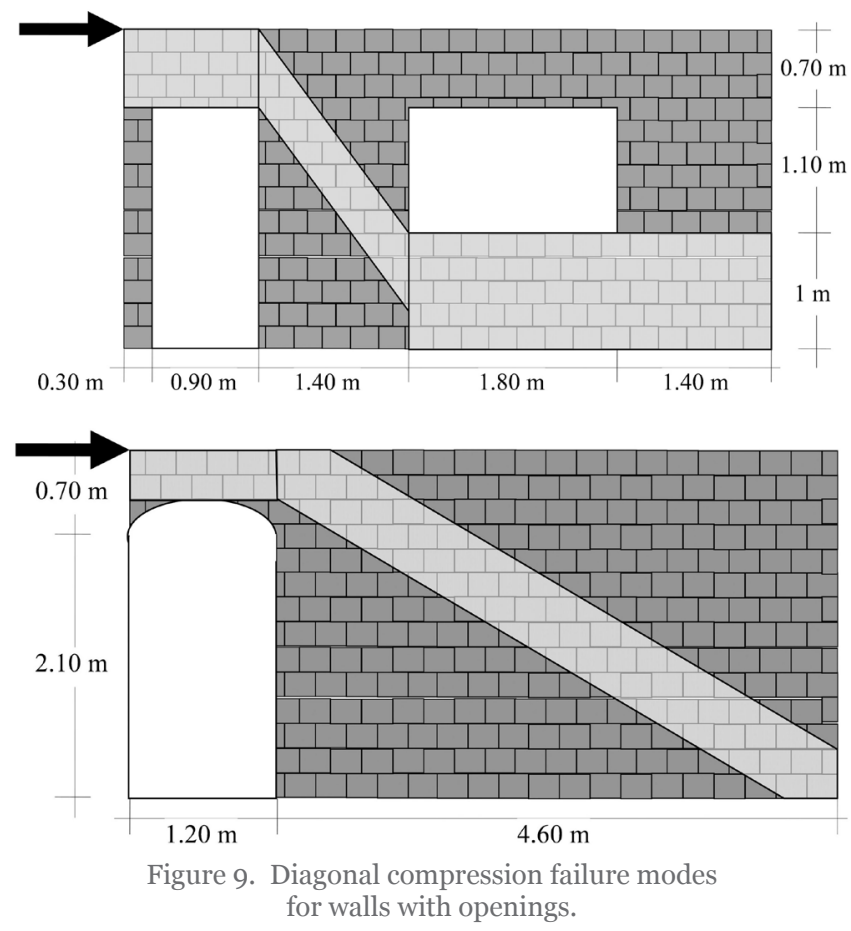

- Detachment of the roof from supporting elements. The roofs are not connected rigidly to the supporting members (i.e. walls and posts) and are therefore at serious risk of falling.

The first three failure modes are global, i.e. they could cause the building to collapse.

Other possible failure modes can be disregarded:

- Out-of-plane failure of the topped walls. These walls rather confined and are vertically compressed; hence, is improbable that this failure comes earlier than the in-plane one.

- In-plane failure of the untopped walls. Since these walls are both laterally unrestrained and uncompressed, their out-of-plane strength is significantly lower than the in-plane one.

- Tension failure of the columns. It is unfeasible, as the elevation aspect ratios of the buildings are low and the masses are small.

- Diagonal tensile cracking of the walls. This is not properly considered as a failure as the construction keeps virtually all its resistant capacity.

- Detachment of the slabs from the supporting frames. This possibility is unfeasible since the slabs are rigid in its own plane (diaphragm effect, mainly due to the top concrete layer) and they are basically encased by the columns.

- Tension failure of the beams in the joints. This failure would mainly arise by slippage of the longitudinal reinforcement bars of the beams that are anchored inside the columns. It is unfeasible as such bars are sufficiently anchored by conventional hooks.

The contribution of the stairs to the initial horizontal strength and stiffness is neglected because they are usually located near stiffer elements (i.e. longitudinal walls for internal stairs or transversal walls for external stairs). Conversely, after wall failure, the additional resistance of the stairs might play a relevant role but it is conservatively not accounted for because of its low reliability. Nonetheless, the stairs are frequently located asymmetrically and they might introduce relevant torsion effects in the building. The repercussion of the openings in the slabs is also neglected as they have little effect in their in-plane resistance. Hence, a full diaphragm effect is assumed and the lateral behavior of the building is represented by lumped masses models with one degree-of-freedom per floor (at each direction) as the buildings are rather symmetric.

To determine the resistance of the buildings, we obtain the most critical combination of the feasible failure modes for each direction, i.e. the weakest loading path. Table 4 shows the expected critical failure modes, strengths and demands for building B1. The demands exceed the strengths in both directions. The resistance in the longitudinal direction is considerably smaller than the transversal resistance, even though the walls are longer and have no openings; this effect is due to the premature shear failure of the posts, caused by the presence of the diagonal compression struts in the walls. The force demands on buildings B2 and B3 are higher than those on building B1 (Table 4), whereas the strengths and critical failure modes are largely the same. The study (5) shows that the cantilevers are at serious risk of collapse due to the vertical input.

The conclusions from this seismic study are compared to the observed damage in two similar situations (5): El Quindío (Colombia) 1999 earthquake (12) (13) and Izmit (Turkey) 1999 earthquake (14) (15). Close RC building types with common deficiencies, in reports from Colombia and Turkey, exhibited similar damage patterns: the unreinforced brittle masonry walls play a critical role in the mechanisms of lateral load strength, which once overloaded, undergo considerable damage and leave the non-ductile RC frame the responsibility to resist the seismic action. Wall damage concentration is found in the lower levels of buildings, where the seismic stresses build-up considerably over the non-ductile $\mathrm{RC}$ frame easily overloading their members and generating the described damage (16) identify the seismic deficiencies in buildings belonging to "low engineered masonry infilled reinforced concrete frame" type as generating the aforemen-

Table 4. Seismic performance of building B1.

\begin{tabular}{|l|l|c|c|}
\hline Direction & Failure mode & Strength (kN) & Demand (kN) \\
\hline$x$ (transversal) & Shearing of cladding and partitioning walls (brittle) & 293 & 309 \\
\hline$y$ (longitudinal) & Shearing of posts and partitioning walls (brittle) & 174 & 309 \\
\hline
\end{tabular}


tioned damage patterns; the most relevant highlights of the research include considerations over the construction quality and position of the masonry infill walls and their role in seismic resistance, which "...act as a first line of seismic defense in a building...”. Consequently, the interaction between RC frame and infill walls is determinant in the seismic performance of the buildings.

\section{SEISMIC STRENGTHENING PROPOSAL}

This section presents feasible strategies for reducing the seismic vulnerability of the non-engineered constructions in "La Milagrosa". It is assumed that all the works will be carried out under expert technical supervision, even when performed by the owners of the buildings; therefore, rather than non-engineered construction, it should be termed "engineered selfconstruction". The main seismic deficiencies can be divided into three broad categories: poor resisting elements, pounding of adjoining buildings, and plan asymmetry (although the latter applies mainly to buildings not represented by the four prototypes). The proposed solutions are described next.

Walls. As mentioned above, the buildings are mainly supported by the cladding and partitioning walls. Consequently, these elements should not, under any circumstances, be partially or totally removed. New openings must be made carefully, using temporary props (vertically continuous down to the foundation) and installing lintels and jambs made with reinforced concrete or steel. If there are partitioning walls which are not vertically continuous down to the foundation, new walls should be erected on the lower levels to guarantee the desired continuity. If possible, all walls which are not inplane with the posts and ties should be moved to in-plane positions. In particular, upper-level cladding walls at the front of the building which are built over the edge of cantilevered slabs should be moved to a position that is in-plane with the frame, which would leave the slabs as balconies. No additional floors should be erected, even in the case of single-story buildings.

Transversal walls. The transversal walls (x direction, both cladding and partitioning walls) should be coated with two layers of reinforced concrete. This will harness the full strength capacity of the existing walls and provide additional lateral strength. The demands shown in Table 4 can be withstood easily. Particular attention should be paid to zones with stress concentrations that influence the collapse mechanism (e.g. corners or toes). The detailing should guarantee an even contact and proper anchorage with the surrounding support-

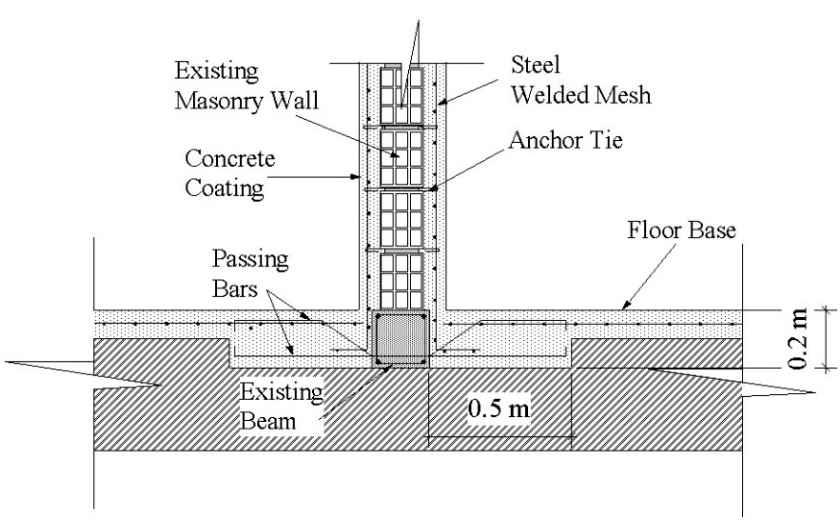

Figure 10. Transversal wall jacketing. ing elements (e.g. slabs, ties and posts) to provide a smooth and sound load transfer. For first-floor walls, foundations are required to ensure a sufficient degree of confinement. Figure 10 shows a sample solution for a common situation.

Longitudinal walls. The longitudinal walls ( $y$ direction) can be strengthened in one of two ways: (i) by placing additional horizontal (hooked) steel reinforcement bars in the bed joints (by temporarily removing part of the mortar, inserting the bar, and re-grouting; see Figure 11, left) (17); or (ii) by lining one or both sides of the wall (Figure 11, right) with anchored layers of reinforced concrete (similar to Figure 10). These measures are intended to increase the strength of the building to all possible failure modes: diagonal compression, horizontal shear and out-of-plane failure. Since these walls support a considerable proportion of the building's weight, this operation should be performed carefully, and props are required (they should be continuous down to the foundation). For first-floor walls, foundations are essential and should be built in the same way as for the transversal walls (Figure 10).

Collar beams. Collar beams (ties) can be connected to the posts to top any untopped wall. These ties can have the same cross section and reinforcement as the frame members already in place. The beams are only intended to tie the upper portion of the wall and to support a light and non-detachable roof. Consequently, a floor must not be built over in any circumstances.

Pounding. If the slabs are unaligned (typically, this occurs in steep sites), stiff and resistant elements (e.g. steel or timber bars) should be placed vertically between two buildings to reduce the most damaging effects of pounding. If the slabs are aligned, elements that are resistant but absorbing (e.g. timber pads) might be placed horizontally between any two adjoining slabs. These measures will reduce the pounding effects and will combine partially the seismic strengths of the two buildings.

Plan asymmetry. Asymmetric buildings can be re-symmetrized by adding infill walls in-plane with the frames or by closing some of the openings.

Roofs. Roofing should not be constructed from heavy materials (tiles, concrete blocks, massive steel members, etc.). Isolating zinc sheathing supported by light steel or timber elements is recommended. Heavy unanchored elements for
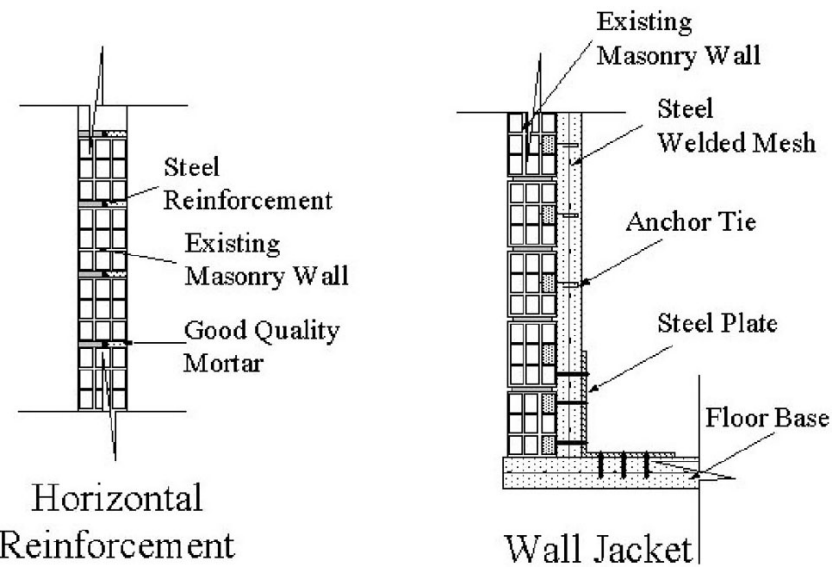

Figure 11. Longitudinal wall strengthening. 
preventing sheathing uplift (bricks, rock, tires, etc.) should not be used because they have a high risk of falling and add considerable weight.

Furniture and appliances. Heavy and tall furniture and appliances should be anchored to the floor or the posts; wall fixtures should be avoided because they could lead to out-ofplane failure.

Sewage. Excretal water should be drained to the public sewage system to prevent soil problems caused by local excess of water.

\section{SEISMIC ANALYSIS OF THE STRENGTHENED BUILDINGS}

This section presents a simplified estimation of the seismic capacity, in terms of equivalent base-shear, of the prototype buildings retrofitted by the approach depicted in the previous section. The strengthening consists of providing additional shear resistance to the walls by jacketing them, as shown by Figure 10 and Figure 11; the recommended concrete compressive strength is $f_{\text {ck }}=20 \mathrm{MPa}$. The shear strength of the jackets is conservatively estimated as the sum of the tensile capacity of the horizontal re-bars and the dowel capacity of the vertical ones:

$$
V_{\mathrm{j}}=C_{\mathrm{rh}} \times A_{\mathrm{rh}} \times f_{\mathrm{yk}}+C_{\mathrm{rv}} \times A_{\mathrm{rv}} \times f_{\mathrm{yk}}
$$

In this expression $V_{\mathrm{j}}$ is the shear strength of the jacket, $C_{\mathrm{rh}}$ $=0.9$ and $C_{\mathrm{rv}}=0.2$ are reduction factors for horizontal and vertical reinforcements, $A_{\mathrm{rh}}$ and $A_{\mathrm{rv}}$ are the horizontal and vertical areas of the reinforcement and $f_{\mathrm{yk}}$ is the steel yielding point. The obtained shear resistances under different jacketing conditions are shown in Table 5 . The yielding point of the steel is $f_{\mathrm{yk}}=500 \mathrm{MPa}$ and the spacing is $0.1 \mathrm{~m}$ in both directions.

Table 5. Shear strength $(\mathrm{kN})$ per wall contributed by jacketing.

\begin{tabular}{|c|c|c|}
\hline Diameter $\mathbf{( m m )}$ & Wall in $x$ direction & Wall in $y$ direction \\
\hline 4 & 219.98 & 218.72 \\
\hline 5 & 343 & 341.04 \\
\hline 7 & 449.75 & 447.18 \\
\hline
\end{tabular}

The coating yields two benefits: to provide the additional strength given by Table 5 and to confine the existing masonry wall thus allowing the full formation of the aforementioned collapse mechanisms. Thus, the lateral resistance of the wallcoating assembly is obtained adding those of the jackets and of the confined wall alone. This strength is largely enough to cope with the code seismic demands; for instance, Table 6 shows the figures for building B1 by assuming $4 \mathrm{~mm}$ re-bars (5).

The original strength in $y$ direction indicated in Table 6 is bigger than the one in Table 4 since the jacketing allows the development of the whole wall strength (5).

\section{DRAFT CONSTRUCTION RECOMMENDATIONS}

A list of important construction recommendations intended for new constructions is included next. The guidelines are cheap and easy to follow (neither uncommon materials nor complicated techniques are suggested), in order not to increase significantly the cost and the difficulty of the construction. No highly skilled workers are required in order to maintain the self-construction nature. However, the expected benefits are important. In any case, it is noticeable that these measures will not guarantee the complete fulfillment of the design codes. The suggested construction process consists basically of erecting the walls before the concrete members (tie-columns and tie-beams); therefore, overall recommendations for confined masonry apply (18). That reference includes a section specific for non-engineered construction; noticeably empirical criteria for selecting the wall density are given.

\subsection{General description of the proposed buildings}

The proposed buildings will be similar to the existing ones, since high deviations from the actual techniques are not considered as to avoid the need of training people. The most relevant innovations are:

- The number of floors is absolutely restricted to two. The construction can be progressive, i.e. the first floor is erected first and, when needed, a second floor is built over. The roof of the second story should be light.

- The cladding and partitioning walls are founded on reinforced concrete stripes. The expected benefit is to guarantee a smooth and even transmission of stresses to the ground. The wall foundations will additionally serve as ties between the columns footings, preventing relative movements between them during strong earthquakes.

- The walls should be vertically continuous (down to foundation) and coplanar with the frames. The benefit is a better structural cooperation between walls and frames.

- The resistant quality of the walls is improved by using better mortar and workmanship. This is relevant as it has been found that the walls carry most of the weight and of the lateral loads.

- The longitudinal walls are reinforced with horizontal steel bars embedded in mortar beds and anchored in the tie-columns. This measure will significantly increase the strength to the diagonal strut compression and the out-of-plane failure modes; this will provide more ductility.

- Stirrups are placed closer, especially near the joints. Major benefits are to avoid premature shear failure of tie-beams and tie-columns, to confine the core concrete and to guarantee ductility.

Table 6. Seismic performance of building B1.

\begin{tabular}{|l|c|c|c|}
\hline Direction & Original Strength $(\mathbf{k N})$ & Final Strength $(\mathbf{k N})$ & Demand $(\mathbf{k N})$ \\
\hline$x$ (transversal) & 273.84 & $2 \times 219.98+273.84=713.80$ & 309 \\
\hline$y$ (longitudinal) & 336.00 & $2 \times 218.72+336.00=773.44$ & 309 \\
\hline
\end{tabular}


- The strength of the cross-sections of the tie-beams and of the tie-columns should be increased by enlarging the depth and the reinforcement amount and/or the steel yielding point. The tie-beams will be $20 \mathrm{~cm}$ wide and 30 $\mathrm{cm}$ deep, while the tie-columns will have the same section $\left(20 \times 30 \mathrm{~cm}^{2}\right)$, where the highest dimension is in the $x$ direction (main resisting frames). Eventually, the use of square sections $\left(30 \times 30 \mathrm{~cm}^{2}\right)$ could be recommended to avoiding the possibilities of construction errors and of eccentricities in the joints.

- All the top floor walls are topped with collar beams. The benefits are more resistance to out-of-plane failure and better support of the roof.

\subsection{Construction process}

As discussed previously, the construction process consists basically of erecting the walls before the tie-columns and tiebeams and to cast them against the walls. The main benefits from this strategy are to confine the walls and to increase its vertical compression (it improves the shear, diagonal compression and out-of-plane strength). This technique has been already used in other non-engineered houses in Mérida.

- Foundations. To lay the reinforced concrete foundations for tie-columns (footings) and walls (stripes). The reinforcements of the first floor tie-columns should be anchored into the footings. Since the length of the commercially available bars is, at least, $6 \mathrm{~m}$, it is advisable to keep their integrity and to form the reinforcement for two consecutive floors without splicing; if the completion of the second floor is delayed for long, the exposed bars should be protected from corrosion. In any case, enough length for splicing (at least $40 \mathrm{~cm}$ ) should be left protruded from the first floor; however, it should be kept on mind that the tie-column base is not the best position for overlapping the longitudinal reinforcement.

- Walls. The first floor infill walls (cladding and partitioning) are erected on the stripe foundations using a stretcher bond. In the longitudinal walls, at $h / 4, h / 2$ and $3 h / 4$, ( $h$ is the height of the wall) the mortar beds must be reinforced with, at least, two steel bars anchored to the tie-columns reinforcement; if required, the height of the mortar bed could be increased to house the bars and to protect them against corrosion. These reinforcements will constitute a kind of simplified ring beam. In the transversal walls, these reinforcements are practically useless if their continuity is interrupted by openings, and only those situated above or below the openings are advised. Moreover, the reinforcements that are above the openings play the role of lintels. As the bond is stretcher, the sides facing the tie-columns are toothed; the voids can be cast, prior to the tie-columns casting, with mortar or concrete to avoid the risk of bad filling during the main casting operation. The bond with the tie-column can be improved by leaving protruding re-bars.

- Molds. The tie-columns will be molded with conventional wooden planks. They can be tied each other by customary techniques using conventional wires. The molds can either cover the whole length of the tie-column or be shorter; this last option will ease the concrete compacting. The tiebeams are molded in the same way as in the existing buildings.

- Casting. The tie-columns are cast by conventional gravity screed. The concrete compacting can be made either by shaking the molds (this operation is possible as they are fixed to the walls) or by striking directly in the mass with conventional steel bars. Some of the holes of the bricks will be partially filled with the fresh concrete, this will benefit the bonding. The workers should be informed that excess of water, yet improves the workability, reduces the strength.

- Steel beams. The structural continuity between the IPN sections and the upper concrete layer is guaranteed by welding shear connectors to the upper flange of the steel beams. The upper endings of these connectors should be flat and aligned horizontally as to provide an even support for the welded mesh. The estimated height is around $2 \mathrm{~cm}$. In this way the mesh is better protected against corrosion and it can cooperate more intensely with the surrounding concrete.

- Slabs. The slabs will be built roughly like in the existing buildings. Bondage may be practiced between the slab and the transverse tie-beams, by leaving protruding steel bars at the upper side of the tie-beam; as well, an empty space before the hollow clay bricks arrangement can be left, it will be filled with concrete when the slab topping is casted. As discussed previously, the mesh is separated $2 \mathrm{~cm}$ from the

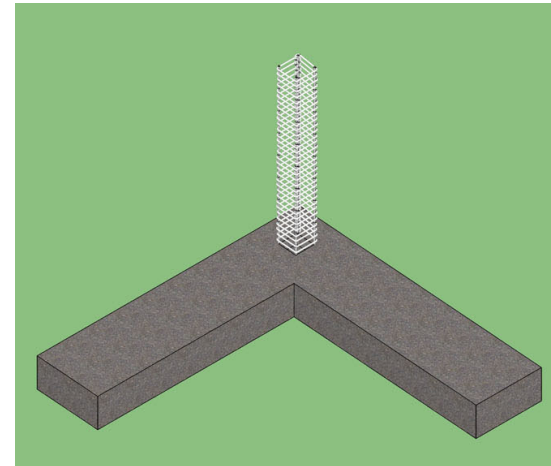

(a) Stripe foundation and tie-column reinforcement

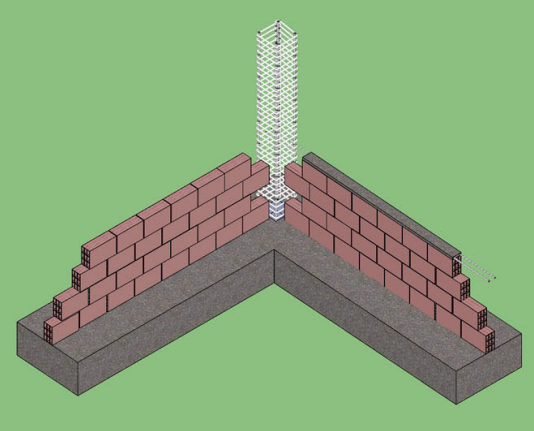

(b) Walls

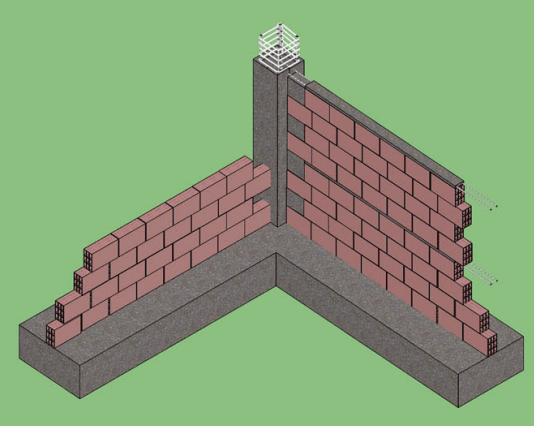

(c)Tie-columns 
upper flange of the steel beams; hence, the minimum total height of the concrete layer is $5 \mathrm{~cm}$.

Figure 12 describes the first three major consecutive operations.

\subsection{Construction details}

- The excretal water should be drained to avoid possible soil problems due to local excess of water, especially in the lower parts of the premises.

- The footings for the tie-columns should be, at least, $50 \mathrm{~cm}$ wide (square) and $30 \mathrm{~cm}$ high. The stripe foundations of the walls should be, at least $50 \mathrm{~cm}$ wide and $30 \mathrm{~cm}$ high.

- The reinforcement for both foundations should be, at least, a steel welded mesh $10 \times 10 \mathrm{~cm}$ with $3 / 8$ " diameter. Anchoring will be obtained by proper hooking.

- Stirrups' hooks should be closed $\left(135^{\circ}\right)$. The main benefit is to improve the confinement of the core concrete.

- The longitudinal reinforcements of the tie-beams should be anchored in the tie-columns by hooking them to their longitudinal bars.

- In the joints between tie-beams and tie-columns, their axes should be coplanar. However, if the sections are not square $\left(20 \times 30 \mathrm{~cm}^{2}\right)$, some minor eccentricities among the axes of tie-beams and tie-columns arise if the tie-beams are aligned with the external side of the tie-columns; this practice is not recommended but the torsion effects in the tie-columns will not be very important since most of the horizontal forces will be carried directly by the slabs.

- Roofing with heavy materials should be avoided to reduce the seismic forces.

- Detachable roof parts with heavy elements (bricks, rock, tires, among others) should be avoided to prevent sheathing uplift, risk of fall and excessive mass.

\subsection{Additional recommendations}

- The building is mainly supported by the walls. Hence, they should not, under any circumstances, be removed (even temporarily) or significantly pierced.

- Plan symmetry should be sought. Major sources of asymmetry are steel stairs and wide openings. The asymmetric buildings can be re-symmetrized by adding coplanar infill walls or by closing openings.
- In sharp or irregular construction sites, the symmetry is still more important. Since construction joints are unfeasible, stiff elements (stairs and good quality and coplanar infill walls) should be placed at both side ends.

- In steep sites, the space between front poles should be filled with masonry walls, mainly in the outer frame to assure structural symmetry parallel to the contour lines.

- Enough seismic gap with contiguous buildings should be kept; mostly in steep sites, where slabs can be misaligned. This avoids the pounding effect.

- Heavy furniture and appliances should be fixed to the floor or to the frame. Connections to the walls should be avoided because of the risk of out-of-plane failure.

- Cantilevered cladding walls should be avoided. It benefits both the behaviors for gravity loads and for the vertical component of the seismic action. Balconies are acceptable as both the dead and live loads are smaller.

\section{CONCLUSIONS}

This work describes a detailed study of the seismic vulnerability of informal constructions in "La Milagrosa" settlement at Mérida, Venezuela. Four prototype buildings are selected to represent most of the dwellings in such settlement. Detailed structural analyses and code-type studies confirm that their seismic performance is inadequate. This information is used to develop simple and inexpensive but effective strengthening measures and to propose construction guidelines for new buildings. These requirements could be termed "low-level engineered self-construction" rather than "non-engineered self-construction"; it means that, taking into account the uses and the socio-economic context of these types of informal settlements, self-construction might be acceptable, although expert technical supervision is essential.

The methodology used in this paper can be applied, with minor modifications, to most of the informal settlements in Central and South America. In addition, the results and conclusions can be extrapolated to many informal settlements in cities located in other seismic-prone areas. Note that "La Milagrosa" was chosen because it is highly representative.

\section{ACKNOWLEDGEMENTS}

This work has received financial support from the Spanish Government under projects CGL2008-00869/BTE y CGL2011-23621. The stay of A. Castillo in Barcelona was funded by the Venezuelan Government (CONICIT), grant \#199601500.

\section{REFERENCES}

(1) ISDR (International Secretariat for Disaster Reduction). (2001). Countering disasters; targeting vulnerability, information kit of the 2001 World Disaster Reduction Campaign. http://www.unisdr.org/2001/campaign/pa-campo1-kiteng.htm.

(2) EERI/IAEE (Earthquake Engineering Research Institute-International Association of Earthquake Engineering). (2005). Encyclopedia of housing construction types in seismically prone areas of the world. http://www.world-housing.net. 
(3) Murty, C.V.R., Brzev, S., Faison, H., Comartin, C.D., Irfanoglu, A. (2006). At risk: the seismic performance of reinforced concrete frame buildings with masonry infill walls. Earthquake Engineering Research Institute-International Association of Earthquake Engineering.

(4) Bolívar, T. (Coordinator). (1994). Densificación y vivienda en los barrios Caraqueños, Contribución a la determinación de problemas y soluciones. Caracas: Consejo Nacional de la Vivienda (CONAVI) - Ministerio de Desarrollo Urbano.

(5) Castillo, A. (2006). Seismic Risk Scenarios for Buildings in Mérida, Venezuela. Detailed Vulnerability Assessment for Non-Engineered Housing (Doctoral Dissertation). Barcelona: Technical University of Catalonia. Available online at: http://www.tdx.cat/TDX-0303106-104140.

(6) Castillo, A., López-Almansa, F., Pujades, L.G. (2011). Seismic risk analysis of urban non-engineered buildings: application to an informal settlement in Mérida, Venezuela. Natural Hazards, 59(2): 891-916, doi: http://dx.doi.org/10.1007/ s11069-011-9805-9.

(7) IAEE. (2001). Guidelines for earthquake-resistant non-engineered construction. International Association of Earthquake Engineering

(8) CEN. (2005). EN-1996 Design of masonry structures. European Committee for Standardization.

(9) MINDUR-FUNVISIS. (2001). Norma COVENIN 1756:2001. Edificaciones Sismorresistentes. Caracas: Dirección General Sectorial de Equipamiento del Ministerio de Desarrollo Urbano - Fundación Venezolana de Investigaciones Sísmicas.

(10) Paulay, T., Priestley, M.N.J. (1992). Seismic design of reinforced concrete and masonry buildings. John Wiley. Doi: http://dx.doi.org/10.1002/9780470172841.

(11) ACI-318. (2011). Building Code Requirements for Structural Concrete (ACI 318-11) and Commentary. American Concrete Institute.

(12) Yoshimura, K., Croston, T., Kagami, H., Ishiyama, Y. (1999). Damage to Building Structures Caused by the 1999 Quindío Earthquake in Colombia. http://www.arch.oita-u.ac.jp/a-kou/STRENG-LAB/paper/PDF/colombia-1.pdf.

(13) Pujol, S., Ramírez, J., Sarria, A. (1999). Coffee Zone, Colombia, January 25 Earthquake, Observations on the Behavior of Low-Rise Reinforced Concrete Buildings. http://nisee.berkeley.edu/lessons/colombia.pdf.

(14) PEER (Pacific Earthquake Enginnereing Center). (2000). PEER 200o/o9: Structural Engineering Reconnaissance of the August 17, 1999 Earthquake: Kocaeli (Izmit), Turkey. http://peer.berkeley.edu/publications/peer_reports/reports_2000/0009.pdf.

(15) USGS (United States Geological Survey). (2000). Implications for Earthquake Risk Reduction in the United States from the Kocaeli, Turkey, Earthquake of August 17, 1999. http://pubs.usgs.gov/circ/2000/c1193/.

(16) Ellul F., D'Ayala D. (2004). On the vulnerability assessment of modern low technology engineered residential construction. En $13^{\text {th }}$ World Conference on Earthquake Engineering, paper $N^{0} 880$. Vancouver, Canada.

(17) Valluzzi, M.R., Binda, L., Modena, C. (2005). Mechanical behavior of historic masonry structures strengthened by bed joints structural repointing. Construction \& Building Materials, 19(1): 63-73, doi: http://dx.doi.org/10.1016/j.conbuildmat.2004.04.036.

(18) EERI/IAEE. (2011). Seismic design guide for low-rise confined masonry buildings. Earthquake Engineering Research Institute-International Association of Earthquake Engineering. http://www.confinedmasonry.org. 